\title{
New Record of Sagami Grenadier, Ventrifossa garmani (Gadiformes: Macrouridae) from Korea
}

\author{
Moon Kyung Jeong ${ }^{1,2}$, Sung Il Lee ${ }^{2}$ and Jin Koo Kim ${ }^{1, *}$ \\ ${ }^{1}$ Department of Marine Biology, Pukyong National University, Busan 608-737, Korea \\ ${ }^{2}$ External Research Cooperation Division, NFRDI, Busan 619-705, Korea
}

\begin{abstract}
A single specimen (149.9 mm TL) of sagami grenadier, Ventrifossa garmani was collected from Korea waters. This species is similar to Coelorinchus spp. in body shape, but is distinguished by a short and rounded snout. It is characterized by having the serrated second dorsal spine in the first dorsal fin, a triangular spine on the scale, seven branchiostegal rays and six scales below middle of first dorsal fin. We describe this species as the first record to Korean fish fauna and propose the Korean name "Kkeo-kkeul-meo-ri-min-tae-sok" for this genus, and "Kkeo-kkeul-meo-ri-min-tae" for this species.
\end{abstract}

Keywords: first record, Sagami grenadier, Macrouridae, Vetrifossa garmani, Korea

\section{INTRODUCTION}

The macrourid fishes belonging to the order Gadiformes comprise four subfamiles, about 27 genera and about 350 species globally (Nelson, 2006) and two genera and seven species in Korea (Kim et al., 2005; Kim et al., 2009). These species distribute on continental shelves or continental slopes throughout the world, except in the Arctic waters (Cohen et al., 1990; Nelson, 2006).

There have been many studies concerning the morphology, ecology and phylogenetic relationships of macrourid fishes around the world (Iwamoto, 1979; Cohen et al., 1990). However, in Korea, only a brief description of three species (Coelorinchus multispinulosus Katayama, 1942, Coelorinchus japonicas (Temminck and Schlegel, 1842), Coelorinchus longissimus Mastubara, 1943) has been reported (Kim et al., 2005). Subsequently four unrecorded species (Coryphaenoides marginatus Steindachner and Döderlein, 1887, Coryphaenoides microps (Smith and Radcliffe, 1912), Coelorinchus macrochir (Günther, 1877), Coelorinchus formosanus Okamura, 1963) were reported in the southern East Sea of Korea (Kim et al., 2009).

During a bottom trawl survey on March 2006, we first collected a macrourid fish in southern East Sea of Korea. We herein described its morphological characteristics and compared it with other macrourid fishes. We identified the species according to Cohen et al. (1990) and Nakabo (2002). Measurements and counts followed Nakabo (2002) and those of Iwamoto (1978). The examined specimen is deposited in

*To whom correspondence should be addressed

Tel: 82-51-629-5927, Fax: 82-51-629-5931

E-mail: taengko@hanmail.net the Pukyong National University (PKU).

\section{SYSTEMATIC ACCOUNTS}

\section{Order Gadiformes}

Family Macrouridae Gilbert and Hubbs, 1916

Genus Ventrifossa Gilbert and Hubbs, 1920

Ventrifossa Gilbert and Hubbs, 1920: 543 (type species: Ventrifossa garmani)

Genus Ventrifossa has seven branchiostegal rays and a moderately pointed to rounded snout. Mouth subterminal, upper jaw length more than 33\% in head length. Mandibular teeth arranged in two rows or in a narrow band. Anus located separately from the origin of anal fin. Light organ small and circular, and segregated from anus. Branchiostegal scales absent, except in subgenus Lucigadus. No mesh structure on scales (Cohen et al., 1990; Nakabo, 2002). There are three subgenera, Ventrifossa, Sokodara, Lucigadus, in genus Ventrifossa (Cohen et al., 1990).

\section{Ventrifossa garmani (Jordan and Gilbert, 1904)}

(Fig. 1, Table 1)

Coryphaenoides garmani Jordan and Gilbert, 1904: 610 (type locality: Sagami Bay, Japan).

Lionurus garmani: Gilbert and Hubbs, 1916: 193.

Ventrifossa garmani: Okamura et al., 1984: 212; Cohen et al., 1990: 300, fig. 678; Nakabo in Nakabo, 2002: 423.

Material examined. PKU 3202, 1 specimen, $149.9 \mathrm{~mm}$ total length (TL), Ulsan, 23 Mar. 2006, bottom trawl. 


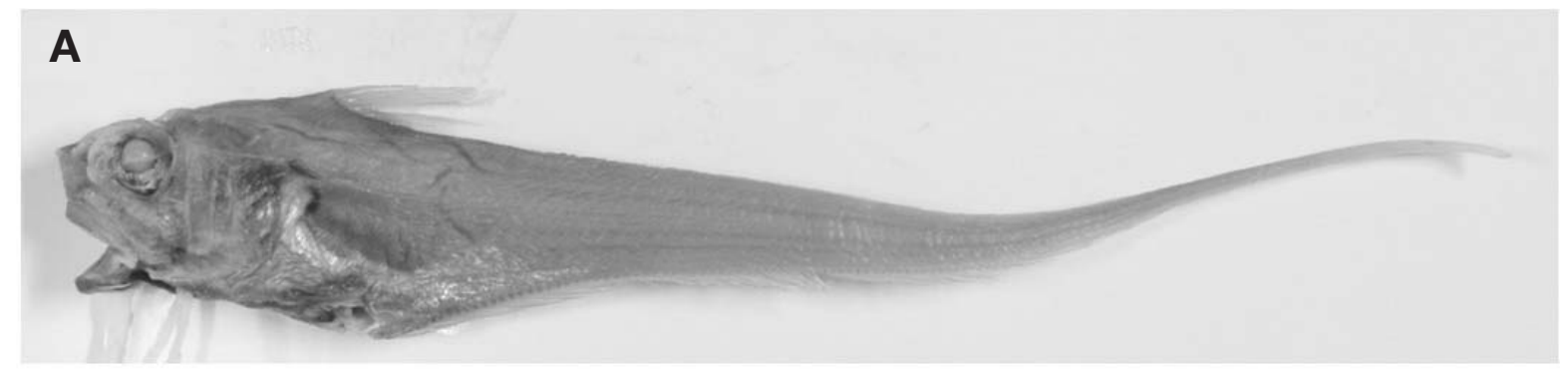

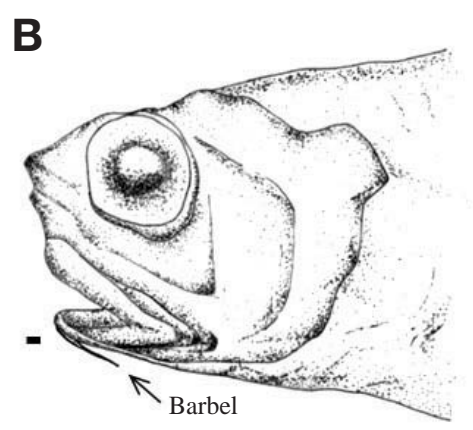

D

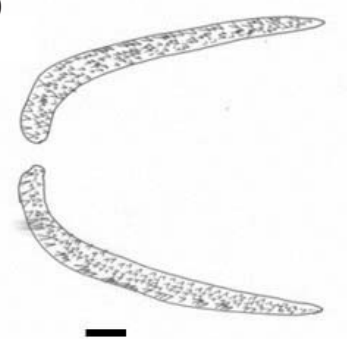

C
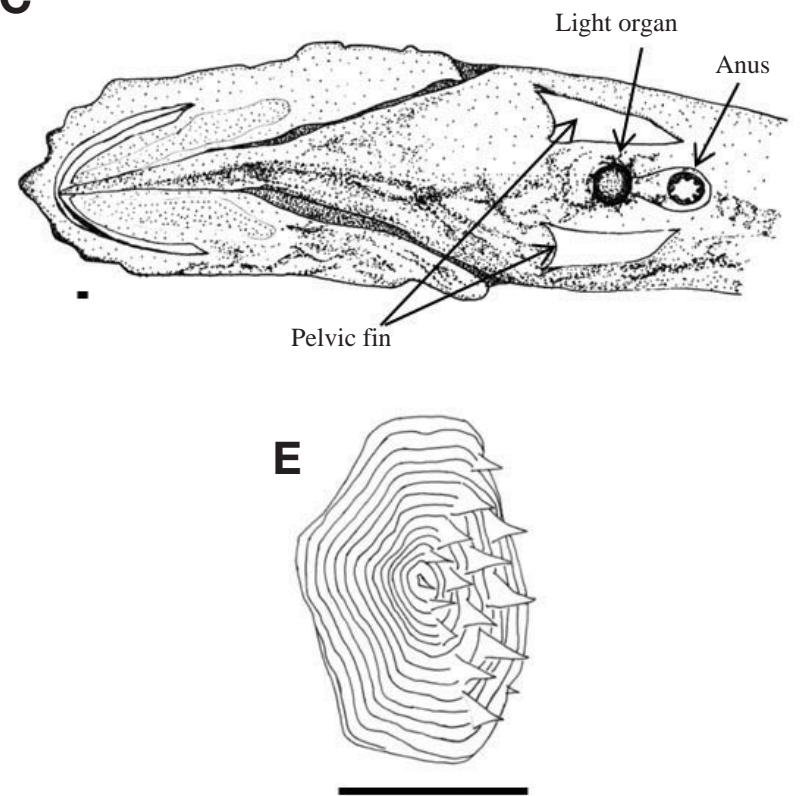

Fig. 1. A, Ventrifossa garmani (Jordan and Gilbert, 1904), PKU 3202, 149.9 mm TL, Ulsan, Korea; $B$, lateral view of head; C, ventral view of head and anterior portion of body; D, upper and lower jaw teeth; E, scale on dorsal body. Scale Bar=1 mm.

Description. $\mathrm{D}_{1}$. II, 11; $\mathrm{P}_{1} .20 ; \mathrm{P}_{2} .8$; GR. 0+13; Trac. 6; BR. 7.

Measurements are shown in Table 1.

Body elongated and compressed, taper to the caudal fin and rapidly narrow behind anus (Fig. 1A); snout short, having small humps, forward stubby; upper jaw extended below to the posterior end of eye (Fig. 1B); membrane of hyoid arch no scales; mouth subteriminal; both jaws having fine teeth; outsider upper jaw teeth larger and wider band than those of insider; lower jaw teeth almost same and formed narrow band (Fig. 1D); one barbel on front of the lower jaw; one light organ between pelvic fins; anus oval, separated from origin of anal fin; origin of pectoral fin corresponded with origin of pelvic fin; second spine of first dorsal fin serrated; several flat triangular spines scattered on body scales; mesh structure absent on scales (Fig. 1E).

Color. Body generally lustrous dark silver grayish when fresh; pectoral fin base and posterior edge of operculum blackish; all fins transparent; after formalin fixation, body overall light brownish; dorsal fin base brownish; silver grayish in front of anal fins (Fig. 1A).

Distribution. Korea (present study), Japan (Jordan and Gilbert, 1904; Nakabo, 2002), East China Sea (Cohen et al., 1990) and Taiwan (Shen et al., 1993)

Remarks. Present specimen is easily identified genus Ventrifossa by chacracteristics of mesh structure absent on scales as well as upper jaw length more than $1 / 3$ head length by Nakabo (2002). Measurements and counts of the present specimen were corresponded with the previous descriptions of $V$. garmani (Table 1). And present specimen was compared with other genus Ventrifossa in Japan (Table 2).

V. garmani was similar to Ventrifossa macroptera Okamura, 1982 in meristics and morphometrics and Ventrifossa saikaiensis Okamura, 1984 in morphology. But they were easily distinguished by position of pelvic fin and pectoral fin and mandibular teeth, respectively. First V. garmani differed 
Table 1. Comparison of meristic and morphometric characters of Ventrifossa garmani

\begin{tabular}{|c|c|c|c|c|}
\hline & Present study & Jordan and Gilbert (1902) & Gilbert and Hubbs (1916) & Okamura et al. (1984) \\
\hline Number of specimens & 1 & 1 & 30 & 3 \\
\hline Total length(mm) & 149.9 & 292 & $113-340$ & $210-292$ \\
\hline \multicolumn{5}{|l|}{ Counts } \\
\hline First dorsal fin rays & II, 11 & II, 10 & - & II, $10-11$ \\
\hline Pectoral fin rays & 20 & $20-21$ & - & $20-21$ \\
\hline Pelvic fin rays & 8 & - & - & $8-9$ \\
\hline Gill rakers & $0+13$ & - & - & $0+11-13$ \\
\hline TRac & 6 & - & 6 & 6 \\
\hline Branchiostegal rays & 7 & - & - & 7 \\
\hline \multicolumn{5}{|l|}{$\%$ in TL } \\
\hline Head length & 16.9 & 18.2 & $20-23.9$ & $15.9-18.5$ \\
\hline Body depth & 15.7 & 15.4 & $14.8-16.5$ & $13.5-15.6$ \\
\hline Predorsal length & 19.1 & - & - & $19.6-20.8$ \\
\hline Preanal length & 22.4 & - & - & $22.2-25.6$ \\
\hline \multicolumn{5}{|l|}{$\%$ in $\mathrm{HL}$} \\
\hline Snout length & 25.4 & 26.3 & $25-27$ & $25.1-29.0$ \\
\hline Upper jaw length & 43.1 & 44.4 & - & $41.7-45.5$ \\
\hline Barbel length & 24.3 & 27.3 & $23.8-26.3$ & $23.8-30.6$ \\
\hline Orbital diameter & 30.5 & 30.8 & $30.7-35.7$ & $30.6-38.5$ \\
\hline Postorbital length & 42.6 & 44.0 & $41.1-45.3$ & $43.4-45.5$ \\
\hline Interorbital length & 29.8 & 27.8 & $32.2-32.9$ & $26.3-29.4$ \\
\hline Subopercle length & 19.1 & - & $11.8-13.3$ & - \\
\hline Prepectoral length & 98.2 & - & - & - \\
\hline Prepelvic length & 107.7 & - & - & - \\
\hline Pectoral fin length & 55.8 & - & 58.8 & 62.5 \\
\hline Pelvic fin length & 32.5 & 43.5 & $37-40$ & $41.7-43.5$ \\
\hline \multicolumn{5}{|l|}{$\%$ in 1 st dorsal fin base } \\
\hline Interdorsal space & 228.5 & $200-250$ & - & $210-220$ \\
\hline
\end{tabular}

Tabel 2. Comparison of meristic and morphometric characters of genus Ventrifossa in Japan

\begin{tabular}{|c|c|c|c|c|c|c|c|c|}
\hline \multirow[b]{2}{*}{ Characters } & \multicolumn{2}{|c|}{ V. garmani } & \multirow{2}{*}{ 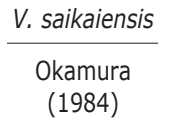 } & \multirow{2}{*}{ 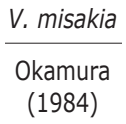 } & \multirow{2}{*}{$\frac{\text { V. rhipidodorsalis }}{\text { Okamura }} \begin{array}{c}(1984) \\
\text { (1984) }\end{array}$} & \multirow{2}{*}{ 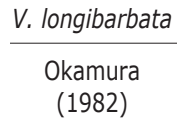 } & \multirow{2}{*}{$\begin{array}{c}\text { V. fusca } \\
\text { Okamura } \\
(1982)\end{array}$} & \multirow{2}{*}{$\begin{array}{c}\text { V. macroptera } \\
\begin{array}{c}\text { Okamura } \\
(1982)\end{array}\end{array}$} \\
\hline & Present study & $\begin{array}{l}\text { Okamura } \\
(1984)\end{array}$ & & & & & & \\
\hline Number of specimens & 1 & 3 & 12 & 1 & 26 & 5 & 4 & 53 \\
\hline Total length (mm) & 149.9 & $210-292$ & $200-312$ & 244 & $160-356$ & $174-296$ & $434-612$ & $258-400$ \\
\hline \multicolumn{9}{|l|}{ Counts } \\
\hline First dorsal fin rays & II, 11 & II, 9-12 & II, 9-11 & $\mathrm{II}, 10$ & II, 9-12 & II, 10 & II, $10-12$ & II, $9-10$ \\
\hline Pectoral fin rays & 20 & $20-21$ & $19-22$ & 19 & $20-24$ & $23-25$ & $20-23$ & $21-26$ \\
\hline Pelvic fin rays & 8 & $8-9$ & $8-9$ & 8 & $9-10$ & 8 & 8 & $9-10$ \\
\hline Gill rakers & $0+13$ & $0+11-13$ & $0+12-15$ & $0+12$ & $0+10-15$ & $0+9-13$ & $0+9-13$ & $0+11-17$ \\
\hline Tra* & 6 & $5-6$ & $7-7.5$ & $9-9.5$ & $5.5-6.5$ & $9-10$ & $9-9.5$ & $6-8$ \\
\hline Branchiostegal rays & 7 & 7 & 7 & 7 & 7 & 7 & 7 & 7 \\
\hline \multicolumn{9}{|l|}{$\%$ in $\mathrm{TL}$} \\
\hline Head length & 16.9 & $15.9-18.5$ & $16.8-18.3$ & 19.6 & $17.3-19.0$ & $16.3-17.7$ & $18.5-19.0$ & $17.2-19.8$ \\
\hline Body depth & 15.7 & $13.5-15.6$ & $14.3-15.2$ & 14.5 & $13.1-17.4$ & $13.8-16.5$ & $14.9-15.2$ & $14.7-18.3$ \\
\hline Predorsal length & 19.1 & $19.6-20.8$ & $19.0-21.4$ & 21.3 & $19.3-21.6$ & $18.5-20.5$ & $19.6-21.3$ & $18.0-20.9$ \\
\hline Preanal length & 22.4 & $22.2-25.6$ & $22.4-24.2$ & 18.9 & $22.4-27.0$ & $21.6-25.0$ & $25.9-25.7$ & \\
\hline \multicolumn{9}{|l|}{$\%$ in $\mathrm{HL}$} \\
\hline Snout length & 25.4 & $25.1-29.0$ & $27.6-30.3$ & 26.3 & $26.9-29.3$ & $26.6-28.8$ & $26.9-28.0$ & $25.1-31.4$ \\
\hline Upper jaw length & 43.1 & $41.7-45.5$ & $45.8-51.9$ & 37 & $41.4-46.4$ & $41.9-46.9$ & $39.8-40.4$ & $44.9-50.0$ \\
\hline Orbital diameter & 30.5 & $30.6-38.5$ & $29.0-30.7$ & 33.3 & $27.7-34.1$ & $31.2-38.0$ & $28.0-29.2$ & $25.1-31.3$ \\
\hline Postorbital length & 42.6 & $43.4-45.5$ & $45.5-49.6$ & 45.5 & $40.7-48.2$ & $39.1-43.7$ & $45.2-47.8$ & $44.6-49.6$ \\
\hline Interorbital length & 29.8 & $26.3-29.4$ & $28.5-31.3$ & 25 & $20.7-25.6$ & $23.0-25.0$ & $30.1-30.7$ & $28.2-33.2$ \\
\hline \multicolumn{9}{|l|}{$\%$ in orbital diameter } \\
\hline $\begin{array}{l}\text { Barbel length } \\
\% \text { in 1st dorsal fin base }\end{array}$ & 79.7 & $77.9-100$ & $115-133$ & 37.0 & $64.3-100$ & $102-127$ & $24.5-26.1$ & $78.0-100$ \\
\hline Interdorsal space & 209 & $210-220$ & $170-210$ & - & $170-250$ & $190-260$ & $180-190$ & $140-230$ \\
\hline
\end{tabular}


from $V$. macroptera by the following characters; mandibular teeth (narrow band and equal inner and outer teeth in $V$. garmani vs. 2 rows and longer inner teeth in V. macroptera); scale behind $1^{\text {st }}$ dorsal fin (spines vs. spineless); spines on scales (widen triangular vs. thin triangular). Next V. garmani differed from $V$. saikaiensis by the following characters; Tra. (6 in V. garmani vs. 7 in V. saikaiensis), barbel (93.4\% in orbital diameter vs. 115-133\%), first dorsal fin (transparency vs. blackish), and distance between first and second dorsal fins (228.5\% in first dorsal fin base vs. 170-210\%). The new Korean name of this species reflected rough head.

\section{ACKNOWLEDGEMENTS}

This is contribution number; RP-2010-FR-024, to the National Fisheries Research and Development Institute (NFRDI) and Pukyong National University.

\section{REFERENCES}

Cohen, D.M., T. Inada, T. Iwamoto and N. Scialabba, 1990. FAO species catalogue. Vol. 10. Gardiform fishes of the world (order Gardiforems). An annotated and illustrate catalogue of cods, hakes, grenadiers and other gardiform fishes known to date. FAO (Food and Agriculture Organization of United Nations) Fisheries Synopsis. pp. 90-311.

Gilbert, C.H. and C.L. Hubbs, 1916. Report on the Japanese macrouroid fishes collected by the United States Fisheries Steamer 'Albatross' in 1906. with a synopsis of the genera. Proceedings of the United States National Museum, 51(2149): 135-214.

Gilbert, C.H. and C.L. Hubbs, 1920, The macrouroid fishes of the Philippine Islands and the East Indies. U.S. Mational Museum Bull. 100. I: 369-588. Figs. 1-40.

Günther, A., 1877. Preliminary notes on new fihwes collected in Japan during the expedition of H.M.S. 'Challenger'. Annals and Magazine of Natural History, ser. 4, 20: 433-446.

Iwamoto, T., 1979. Eastern Pacific macrourine grenadiers with seven branchiostegal rays (Pisces: Macrouridae). Proceedigns of the California Academy of Sciences, ser. 4, 42: 135-179.

Jordan, D.S. and E.P. Starks, 1902. List of Fishes dredged by the streamer Albatross off the coast of Japan in the summer of 1900, with descriptions of new species and a review of the Japanese macrouidae. Bulletin of U.S. Fish Commition, 1902: 577-630. Figs. 1-8.

Kim, I.S., Y. Choi, C.L. Lee, B.J. Kim and J.H. Kim, 2005. Illustrated book of Korean fishes. Kyo-Hak Publishing Seoul, Korea, pp. 172-173 (in Korean).

Kim, S.Y., T. Iwamoto and M. Yabe, 2009. Four new records of Grenadiers (Macrouridae, Gadiformes, Teleostei) from Korea. Korean Journal of Ichthyology, 21: 106-117.

Nakabo, T., 2002. Fishes of Japan with pictorial keys to the species, English edition. Tokai University Press. I: i-lxi+1866.

Nelson, J.S., 2006. Fishes of the world. $4^{\text {th }}$ edition. John Wiley and Sons. New York, pp. 235-239.

Okamura, O., K. Amaoka and F. Mitani, 1982. Fishes of the Kyushv-Palav Ridge and Tosa Bay. Japan Fisheries Resource Conservation Association, Tokyo, pp. 144-159. (in Japanese and English)

Okamura, O. and T. Kitajima, 1984. Fishes of the Okinawa Trough and the adjacent waters. The intensive research of unexploited fishery resources on continental slopes. Japan, Tokoy. Fish. Res. Con. Ass. I: 208-215 (in Japanese and English; various authors).

Sazonov, Y. and Y.N. Shcherbachev, 1997. The composition and some problems pertaining to the variability of species of subgenus Sokodara (Genus Ventrifossa, Macrouridae). J. Ichthyol. 37(7): 528-533.

Shao, K.T., 2001. Family Macrouridae. In: Fishes of Taiwan. Reversed ed (Ed., S.C. Shen). National Taiwan University Press, Taipei, pp. 167-173 (In Chinese).

Received May 26, 2010 Accepted November 12, 2010 